\title{
PENGUNGKAPAN LINGKUNGAN DAN ETIKA AL QUR'AN PADA PERUSAHAAN TAMBANG DI INDONESIA
}

\author{
Dessy Noor Farida \\ Fakultas Ekonomi dan Bisnis Islam \\ UIN Walisongo \\ Riwayat Artikel: dikirim Oktober 2018, diterima September 2018, diterbitkan September 2018
}

\begin{abstract}
ABSTRAK
Industri pertambangan sering dinilai menyebabkan kerusakan lingkungan yang besar dibandingkan dengan perusahaan lainnya. Namun disaat bersamaan, industry pertambangan juga terus mendorong praktik pertambangan yang ramah lingkungan (green mining). Industry tambang juga memberikan kontribusi yang besar bagi masyarakat dan negara. Permasalahan lingkungan tidak lagi menjadi permasalahan yang terpisah dari agama, karena agama ddiyakini menjadi salah satu unsur kuat untuk mempengaruhi perilaku individu, kelompok dan masyarakat secara keseluruhan. Penelitian ini bertujuan untuk mengetahui seberapa besar pengungkapan yang dilakukan oleh perusahaan pertambangan yang listing di JII selama 3 tahun berturutturut selama tahun 2015-2017. Metode penelitian yang digunakan adalah content analysis dari annual report yang di laporkan perusahaan. Penelitian ini menemukan fakta bahwa perusahaan pertambangan sudah mengungkapkan hampir semua unsur yang harus diungkapkan menurut pengungkapan pertanggungjawaban lingkungan berdasarkan Al-Qur'an. Hal ni ditunjukkan dengan hampir semua komponen di ungkapkan lebih dari $50 \%$ dari total pengungkapan.
\end{abstract}

Kata Kunci : Pertanggungjawaban lingkungan, Etika Al-Qur'an, perusahaan pertambangan

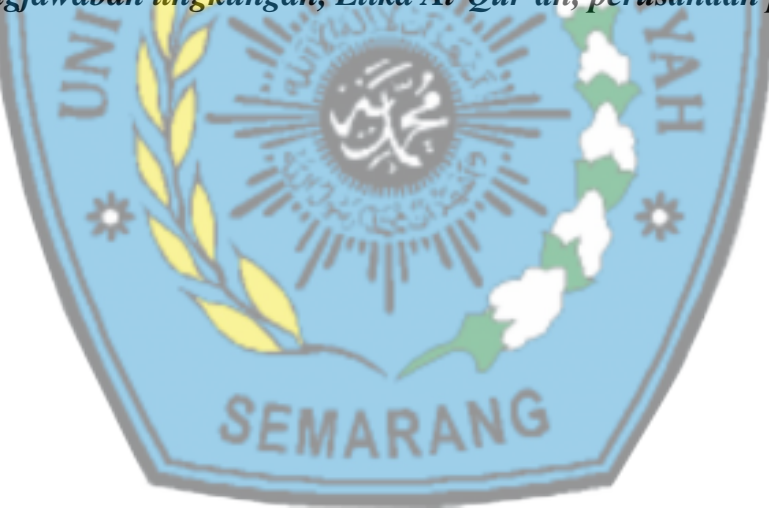




\section{PENDAHULUAN}

Selama beberapa tahun terakhir isu lingkungan menjadi topik yang sangat penting bagi perusahaan. Hal ini disebabkan semakin tingginya kepedulian masyarakat maupun organisasi dalam menjawab permasalahan limgkungan yang terjadi. Isu lingkungan global di Indonesia terkait dengan pencemaran udara, krisis energi, krisis air, perubahan iklim, deforestrasi, kerusakan keanekaragaman hayati dan tata guna lahan, pencemaran bahan beracun dan logam berat, pengelolaan sampah dan kerusakan serta pencemaran laut.

Seiring dengan berkembangnya isu lingkungan, penelitian terkait dengan tanggungjawab lingkungan telah menjadi salah satu subjek yang banyak diminati dalam literatur Corporate Social Responsibility (CSR). Penelitianpenelitian yang dilakukan masih belum memberikan hasil yang memuaskan, karena penelitian tersebut hanya ingin memahami perilaku lingkungan perusahaan dan untuk mengetahui sejauh mana kepatuhan perusahaan terhadap aturan pertanggungjawaban lingkungan. Menurut survey yang dilakukan oleh WEF (The World Economic Forum) secara umum, upaya regulator untuk membentuk mekanisme pembangunan yang berkelanjutan belum menghasilkan efek nyata pada skala yang besar. Hal ini mencerminkan bahwa sekalipun ada peraturan formal, tidak membuat perusahaan sadar dengan sendirinya terkait dengan pelestarian lingkungan (Abdelzaher \& Abdelzaher, 2015).

Industry tambang sering dinilai menyebabkan kerusakan lingkungan yang besar dibandingkan dengan perusahaan lainnya. Namun disaat bersamaan, industry pertambangan juga terus mendorong praktik pertambangan yang ramah lingkungan (green mining). Industry tambang juga memberikan kontribusi yang besar bagi masyarakat dan negara. Setiap orang pasti bergantung pada produk hasil pertambangan dari batu bara untuk listrik, mineral untuk elektronik, sampai logam mulia untuk perhiasan (VOA Indonesia). Menurut VOA Indonesia, sector pertambangan mempunyai dampak lingkungan yang tidak sedikit. Laporan Jaringan Advokasi Tambang (JATAM) mengungkapkan, aktivitas pertambangan batubara meninggalkan tanah yang tandus, daerah tangkapan air yang terkena polusi dan air tanah yang habis. JATAM menemukan 3.033 lubang tambang bekas batubara di Kalimantan Timur yang tidak di tutup kembali sehingga menyebabkan jatuhnya korban.

Masalah lingkungan lain yang pernah terjadi di Indonesia adalah kasus Freeport. Hal ini dibuktikan dengan adanya kesulitan PT Freeport Indonesia dalam mendapatkan dana dari bank asing, karena masih adanya isu lingkungan yang belum diselesaikan oleh perusahaan PT Freeport. Pelanggaran lingkungan yang dilakukan oleh PT Freeport Indonesia berupa penggunaan Kawasan hutan lindung dalam kegiatan operasional tanpa izin (CNN Indonesia)

* Masalah lingkungan sudah sejak lama menjadi pusat perhatian, diawalai pada tahun 1992 di Rio de Janeiro pada KTT Bumi PBB. Perusahaan sebagai penyumbang terbesar permasalahan lingkungan sudah banyak mengadopsi beragam pendekatan untuk mengatasi keprihatinan masyarakat tentang lingkungan. Menurut Egri dan Pinfield (1996) dalam (Helfaya \& Moussa, 2017) corporate environmentalism telah muncul sebagai pendekatan reformis untuk mengatasi permasalahan lingkungan yang dihadapi perusahaan melalui pengembangan strategi manajemen lingkungan. Hal ini menyebabkan adanya 2 tema utama environmetalisme perusahaan yaitu orientasi lingkungan perusahaan dan strategi lingkungan perusahaan. Dalam hal memenuhi kebutuhan para pemangku kepentingan, orientasi lingkungan perusahaan berfokus pada internal yaitu pada nilai-nilai 
perusahaan, standar perilaku etis dan komitmen terhadap perlindungan lingkungan (Freeman et al, 2000). Ketika perusahaan berfokus pada keunggulan kompetitif, strategi lingkungan perusahaan akan mempertimbangkan implikasi strategis dari permasalahan lingkungan yang diintegrasikan ke dalam proses perencanaan strategis (Banerjee, 2002).

Triple bottom line muncul dengan tujuan memperbesar tanggungjawab bisnis dalam berkontribusi pada kesejahteraan masyarakat secara umum dan integritas lingkungan (Ekwueme, Egbunike, \& Onyali, 2013). Hal ini menyebabkan perusahaan berusaha memaksimalkan laba dengan memepertimbangkan kepentingan semua para pemangku kepentingan perusahaan dan mencerminkan tanggungjawab social dan lingkungannya, sehingga perusahaan bertindak sebagai pihak yang bertanggungjawab secara etis.

Konsep pertanggungjawaban lingkungan perusahaan sering dianggap sebagai mekanisme untuk memperbaiki citra dan reputasi perusahaan dengan mencitrakan perusahaan yang bertanggungjawab terhadap lingkungan. Akan tetapi selama lebih dari dua dekade, berbagai permasalahan lingkungan terus bertambah (misalkan emisi gas rumah kaca, kelangkaan air, degradasi tanah, hilangnya keanekaragaman hayati, lapisan ozon yang semakin tipis dll). Hal ini membuktikan bahwa pendekatan lingkungan perusahaan selama ini kurang dapat mengubah sikap perusahaan dalam upayanya mengatasi permasalahan lingkungan.

Perkembangan penelitian terkait etika lingkungan yang dihubungkan dengan ajaran agama sudah banyak dilakukan. Hal ini dikarenakan adanya pemikiran bahwa pelestarian lingkungan merupakan bentuk pertanggungjawaban alam yang telah dititipkan oleh Tuhan untuk kemaslahatan Bersama. Kepercayaan terhadap agama merupakan salah satu unsur kuat yang mempengaruhi perilaku individu, kelompok dan masyarakat secara keseluruhan (Hope \& Jones, 2014). Beberapa penelitian telah membuktikan bahwa tiga agama monotheistic yaitu yudhaisme, Kristen dan islam, dapat mempengaruhi kepribadian individu terkait dengan kesejahteraan masyarakat dan kelestarian lingkungan ((Beekun \& Badawi, 2005)(Kamla, Gallhofer, \& Haslam, 2006)(Yook, Song, Patten, \& Kim, 2017)

Dalam ajaran islam, terdapat dua unsur utama yaitu ibadah dan muamalah (transaksi). Ibadah merupakan kaitan antara hubungan antara individu dengan Tuhan, sedangkan muamalah berkaitan dengan hubungan antara sesama individu dalam kehidupan sehari-hari. Kedua elemen tersebut harus berjalan beririgan agar tercipta kesejahteraan hidup, untuk tercapainya 5 tujuan syariah (maqasid shari;ah) yaitu untuk melindungai iman/agama (din), diri manusia (nafs), kecerdasan (aql), keturunan (nsl) dan kekayaan (maal) (Al Najjar, 2008). Sehingga perlakuan manusia terhadap lingkungan selalu mengandung unsur ibadah dan muamalah.

Dalam ajaran islam, Al-Qur'an telah menegaskan bahwa manusia sebagai khalifah Allah yang mempunyai tugas menjaga alam semesta. Hal ini dijelaskan pada QS 35: 39 yang artinya :

" Dialah yang menjadikan kamu khalifah dimuka bumi ini Barang siapa yang kafir maka kekafiranya menimpa dirinya sendiri. Dan kekafiran orang yang kafir itu tidak lain hanya akan menambah kemurkaan pada sisi tuhannya dan kekafiran orang yang kafir itu tidak lain hanyalah akan menambah kerugian mereka belaka"

Penjelasan dari ayat diatas adalah manusia diciptakan untuk menyembah Allah, dengan bertindak selaras dengan hokum-hukum Allah, sebaliknya jika 
manusia menyalahgunakan amanah yang diberikan Allah atau melanggar hukum dan agama maka akan membawa kehancuran dan kerugian di akhirat. Sebagai makhluk social, manusia memiliki kebutuhan ekologis dan biologis, missal memerlukan air, makanan, tempat berlindung, komunitas dan alam. Dengan demikian manusia perlu memanfaatkan sumber daya alam untuk memenuhi kebutuhannya. Semua makhluk memiliki hak yang sama untuk memanfaatkan sumber daya alam. Dalam Al Qur'an juga banyak ayat yang menyatakan bahwa manusia harus menggunakan sumber daya bumi sesuai kebutuhan dan tidak berlebih-lebihan, agar alam tidak rusak ((Rizk, 2014).

Agama dapat membentuk pengaruh yang kuat pada nilai-nilai, sikap dan perilaku individu. Agama juga dapat mengarahkan bagaimana individu harus memperlakukan alam dan bertindak terhadap semua elemen baik yang hidup maupun yang tidak hidup. Dalam beberapa dekade terakhir, peranan agama dalam memperbaiki lingkungan mulai tumbuh, hal ini biasanya disebut dengan ekologi spriritual. Dalam ajaran agama islam, mengatakan bahwa manusia adalah khalifah dimuka bumi, yang berarti bahwa mereka sebagai pelayan, perwakilan dan agen Allah sebagaimana terdapat dalam Al Qur'an surat Al Baqarah ayat 30 . Dalam pandangan islam, pertanggungjawaban yang harus dilakukan manusia tidak hanya sebatas pada sesama manusia saja, tetapi jauh lebih luas lagi, yaitu kepada Tuhan yang Maha Kuasa (Al-Qur'an 99: 6-8). Pertanggungjawaban ini tidak hanya terkait dengan urusan pribadi saja tetapi juga hampir seluruh aspek kehidupan (bisnis, sosial, politik, ekonomi dll).

Dalam Al Qur'an Surat Al Baqarah ayat 29 yang berisi tentang masyarakat memiliki hak yang sama atas pemanfaatan sumber daya alam yang telah disediakan oleh Tuhan. Manusia tidak diberikan hak milik tetapi diberikan hak untuk memanfaatkan dan mengelola secara wajar dan disertai dengan pelestarian alam, sehingga dapar dimanfaatkan oleh generasi berikutnya. Oleh sebab itu, pemanfaatan alam adalah untuk kepentingan manusia yang dibatasi dengan atura-aturan untuk kemaslahatan bersama.

\section{METODE PENELITIAN}

Dalam penelitian ini, sampel yang digunakan dalah perusahaan pertambangan yang listing di Jakarta Islamic Index, yang konsisten listing selama 3 tahun berturt-turut, yaitu dari tahun 2015-2017. Penelitian ini menggunakan metode content of analysis terhadap annual report terkait dengan pertanggungjawaban lingkungan oleh perusahaan-perusahaan tambang yang listing di JII. Penelitian ini mengkaji lebih dalam 7 elemen pertanggungjawaban lingkungan yang diatur dalam Al Qur'an, yaitu air, udara, tanaman, binatang, tanah, manusia dan sumber daya alam lainnya.

Dalam penelitian ini menggunakan Teknik scoring dengan tahapan sebagai berikut :

a. Memberikan skor untuk setiap item variable yang diungkapkan dalam laporan tahunan khususnya laporan pertanggungjawaban lingkungan, jika satu item diungkapkan maka akan diberikan skor satu (1) dan jika tidak diungkapkan akan diberikan skor nol (0).

b. Skor yang diperoleh pada variable penelitian akan dijumlahkan untuk mendapatkan total skor pengungkapan masing-masing elemen pada perusahaan pertambangan.

c. Menghitung scor kelengkapan pengungkapan dengan menggunakan metode perhitungan index Wallace, yaitu dengan membagi total skor yang diperoleh dengan skor maksimal. 
d. Melakukan eksploring terhadap hasil penelitian lalu memberikan kesimpulan dari hasil penelitian.

\section{HASIL DAN PEMBAHASAN}

Dari perusahaan pertambangkan yang listing di JII (Jakarta Islamic Index) hanya ada 2 perusahaan pertambangan yang listing selama 3 tahun berturut-turut (2015-2017). Perusahaan pertambangan tersebut adalah PT. Adaro Energy dan PT. Vale Indonesia. Dalam penelitian ini akan dideskripsikan bagaimana pengungkapan yang dilakukan oleh kedua perusahaan pertambangan tersebut berdasarkan ayatayat dalam Al Qur'an yang mengatur terkait dengan item-item yang harus diungkapkan dalam pelestarian lingkungan. Berdasarkan hasil penelitian yang dilakukan oleh Helfaya, ada beberapa item yang harus diungkapkan oleh perusahaan pertambangan ketika meggunakan Etika A1 Qur'an. Diantaranya adalah human beings (manusia), air (water),Tanah (land) ,tanaman (plant) dan (sumberdaya yang berhubungan lainnya (other related resources).

PT Vale Indonesia merupakan perusahaan pertambangan global yang mengoperasikan tambang nikel open pit dan pabrik pengolahan di Sorowako, Sulawesi. Perusahaan Vale Indonesia merupakan produsen nikel terbesar di Indonesia dan merupakan perusahaan pemasok 5\% pasokan nikel dunia. Nilai perusahaan terdiri dari 4 nilai yaitu kehidupan adalah yang terpenting, menghargai karyawan, menjaga kelesatarian bumi dan melakukan hal yang benar. Pelestarian alam juga menjadi salah satu visi perusahaan, dimana visi perusahaan adalah menjadi perusahaan sumberdaya alam nomor satu di Indonesia yang menggunakan standar global dalam menciptakan nilai jangka Panjang, melalui keunggulan kerja dan kepedulian terhadap manusia dan alam. Komitmen perusahaan dalam pelestarian lingkungan dapat dilihat dari diraihnya penghargaan Aditama untuk pengelolaan lingkungan "terbaik dari yang terbaik" selama 2 tahun berturut-turut. Selain itu perusahaan juga mendapat penghargaan Blue Proper Achievement. Aktivitas perusahaan Vale Indonesia adalah menjalankan usaha eksplorasi, penggalian, pengolahan, penyimpanan dan operasi nikel. Sehingga, jika perusahaan tidak melakukan kegiatan pelesatrian lingkungan akan menyebabkan kerusakan alam yang dapat merugikan banyak pihak.

PT Adaro Energy merupakan perusahaan yang bergerak di sector batubara, energy, utilitas dan infrastruktur pendukung. Lokasi utama tamang PT Adaro Energy terletak di Kalimantan Selatan, dimana di tempat tersebut ditambangnya envirocoal, batubara termal dnegan kadar polutan yang rendah. Adaro Energy memiliki model bisnis terintegrasi yang terdiri dari delapan pilar yaitu, Adaro Mining, Adaro Services, Adaro Logistic, Adaro Power, Adaro Land, Adaro Water, Adaro Capital dan Adaro Fondation. Salah satu misi PT Adaro Energy adalah mengutamakan keselamatan dan kelestarian hidup. Hal ini membuktikan bahwa PT Adaro Energy tetap memperhatikan kelestarian lingkungan sekitar sebagai bentuk pertangungjawabannya terhadap alam dan masyarakat sekitar. Produk unggulan yang di produksi oleh Adaro Energy adalah Envirocal yang merupakan produk batubara dengan kandungan polutan rendah. Produk ini merupakan merupakan produk yang ramah lingkungan dan ramah biaya. Dari annual report yang disajikan cukup banyak penghargaan yang sudah diperoleh Adaro Energy terkait dengan pelestarian lingkungan diantaranya adalah CSR Indonesian Award, Peringkat Emas Indonesian Sustainable Development Goals Awards, peringkat emas indoneisan CSR Award untuk kategori penigkatan akses air bersih dll.

\section{Pengungkapan terkait dengan kemanusiaan (Human Beings)}


Pengungkapan terkait dengan kemanusiaan yang diungkapkan oleh kedua perusahaan tambang digambarkan dari chart berikut ini :

Gambar 1. Pengungkapan Kemanusiaan

Perusahaan Tambang yang Listing di JII

\section{PENGUNGKAPAN KEMANUSIAAN}

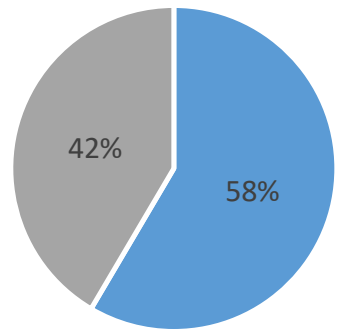

- 1 ADARO $=2$ INCO

Pengungkapan yang terkait dengan

kemanusiaan yang dimaksud adalah bagaimana perusahaan bertanggungjawab terhadap perlindungan makhluk hidup dan yang tidak hidup. Dari data yang ada menunjukkan bahwa PT Adaro Energy sudah mengungkapkan hampir semua hal yang terkait dengan pengungkapan kemanusian menurut $\mathrm{Al}-$ Qur'an ethic dibandingkan dengan PT Vale Indonesia. Dari semua indicator peengungkapan PT Adaro Energy mengungkapkan $100 \%$ dari keseluruhan item dan $\mathrm{T}$ Vale Indonesia hanya mengungkapkan $71 \%$. Didalam sustainability report yang di laporkan oleh perusahaan Adaro Energy, kegiatan operasional perusahaan tersebut sangat memprioritaskan kesehatan dan keselamatan kerja bagi seluruh karyawannya. Hal ini ditunjukkan dengan adanay Lost Time Injury Frequency Rate (LTIFR) yang rendah yaitu sebesar 0.12. hal lain yang dilakukan oleh PT Adaro Energy adalah melakukan inovasi untuk mencegah kecelakaan kerja, salah satunya adalah adanya program fitness for work yang bertujuan untuk meningkatkan kebugaran para pekerja agar dapat selalu bekerja dengan produktif dan aman.

Sedangkan pengungkapan yang dilaporkan PT Vale Indonesia terkait dengan kemanusiaan adalah dengan membangun dan memelihara kota modern dengan fasilitas yang cukup lengkap seperti rumah sakit, sekolah, perbankan, kantor pos, kantor polisi sampai dengan system air minum an pembuangan air kotor. Selama periode 2015-2017 Vale Indonesia telah mencapai lebih 34 juta jam kerja tanpa kejadian yang mengakibatkan wktu kerja hilang dan korban jiwa. Hal ini menyebabkan perusahaan dianugrahi Aditama Safety Award peringkat emas. Dalam melindungi para pekerjanya, perusahaan juga menyediakan fasilitas dan peralatan $\mathrm{K}-3$ sesuai dengan system manajemen $\mathrm{K} 3$ seperti pemakaian masker gas, system ventilasi dan sanitasi serta alat pelindung diri. Selain itu semua alat yang dipakai sudah tersertifikasi sehingga keamanan kerja lebih terjamin.

PT Adaro Energy dan PT Vale Indonesia memberikan kesempatan yang setara kepada setiap karyawannya untuk mengikuti pelatihan dan pendidikan. Bentuk pelatihan dan Pendidikan yang sering diadakan adalah in house training dan knowledge sharing.

Pengungkapan pelestarian Air (Water) Untuk pengungkapan terkait dengan pelestarian air, data menunjukkan bahwa PT Adro Energy juga mengungkapkan hampir seluruh dari item pengugkapan berdasarkan Al-Qur'an ethic, yaitu $100 \%$ sedangkan PT Vale Indonesia hanya mengungkapkan 33\% saja. 
Gambar 2. Pengungkapan Pelestarian

Air

Perusahaan Tambang yang Listing di JII

PENGUNGKAPAN PELESTARIAN AIR

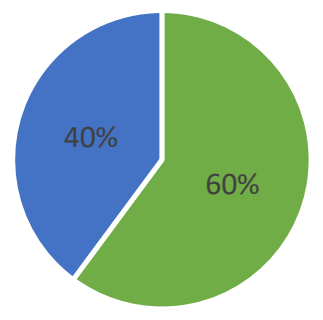

- 1 ADARO 2 INCO

Dari pengungkapan yang dilaporkan oleh Adaro Energy, perusahaan sangat memantau kualitas air buangan dari kolam pengendapan secara berkala dengan menggunakan 5 parameter yaitu tingkat keasaman $(\mathrm{pH})$, kadar zat padat tersuspensi (TSS), kandungan zat besi $(\mathrm{Fe})$, kandungan mangan $(\mathrm{Mn})$, dan kandungan cadmium (Cd). Dari laporan sustainability perusahaan Adaro Energy mengungkapkan bahwa berdasarkan sampel air buangan yang diambil perusahaan selama tahun 2017, nilai ratarata untuk kelima parameter diatas telah memenuhi ketentuan baku mutu yang disyaratkan.

Sedangkan upaya yang dilakukan Perusahaan Vale Indonesia dalam pelestarian air adalah melakukan inovasi dengan membuat teknologi Lamella Gravity Settlers, yang menajdi teknologi pertama di Indonesia untuk mengolah air tambang secara lebih efisien. Selain itu, upaya yang telah dilakukan perusahaan Adaro Energy untuk pelestarian air adalah dengan mengelola air tambang dengan menggunakan 19 kolam pengendapan yang dibangun I wilayah operasi. Pembaharuan lain yang dlakukan oleh perusahaan Adaro Energy adalah dengan memasang geotube untuk meminimalkan dampak ligkungan hidup, dan ini menjadikan Adaro Energy menjadi perusahaan pertama di Indonesia yang menggunakan teknologi yang tidak membutuhkan area ddisposal yang luas.

0 Pengungkapan yang dilaporkan oleh PT Vale Indonesia terkait dengan pelestarian air adalah dengan membangun dan mengoperasikan kolam-kolam sedimentasi di daerah tambang yang masih aktif dan tambang tidak aktif serta menutup material kerokan dengan tanah penutup untuk menghindari terjadinya resuspensi.

Pengungkapan Pelestarian Tanah (Land)

Dalam pengungkapan terhadap pelestarian tanah, terlihat dari gambar bahwa PT Adaro Energy mengungkapkan sebesar $45 \%$ dan PT Vale Indonesia sebesar $55 \%$. 
Gambar 3. Pengungkapan Pelestarian Tanah

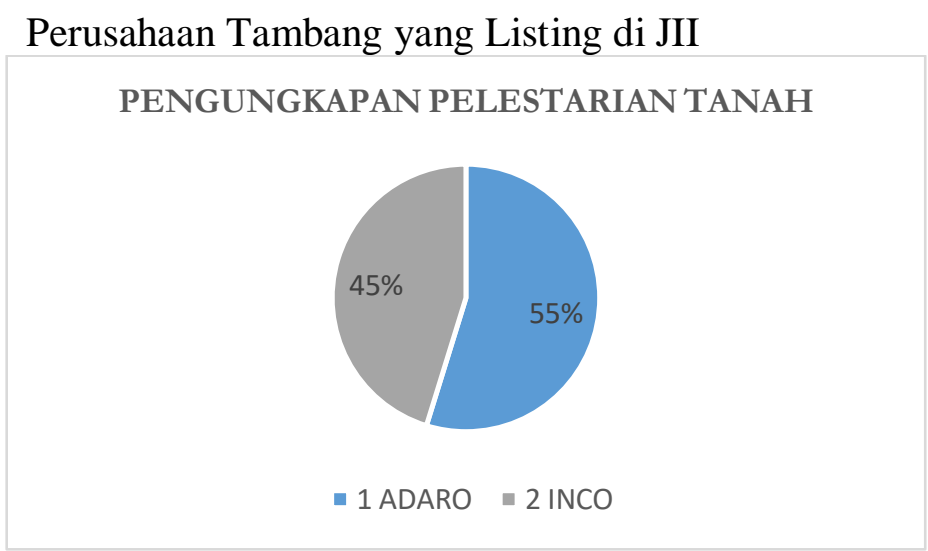

Pengungkapan yang di laporkan oleh Adaro Energy terkait dengan upaya

perusahaan dalam melestarikan memiliki kebijakan untuk membatasi tanah adalah dengan melakukan kegiatan reklamasi untuk merehabilitasi lahan terganggu di wilayah-wilayah penambangan, diantaranya aadalah pembukaan area tambang. Selain itu dengan mengatur permukaan lahan bekas penempatan tanah penutup untuk tambang untuk meminimalkan resiko memastikan stabilitas lereng jangka erosi dan destabilitas lereng, Panjang serta menyebar tanah pucuk di mengendalikan erosi dengan membuat lokasi penempatan akhir tanah penutup bangunan pengendali erosi dan perawatan untuk reklamasi. drainase area reklamasi.

Perusahaan Vale Indonesia Pengungkapan terkait dengan mengungkapkan, bahwa terkait dengan Pelestarian Tanaman (Plant) pelestarian tanah, maka perusahaan

Gambar 4. Pengungkapan Pelestarian Tanaman Perusahaan Tambang yang Listing di JII

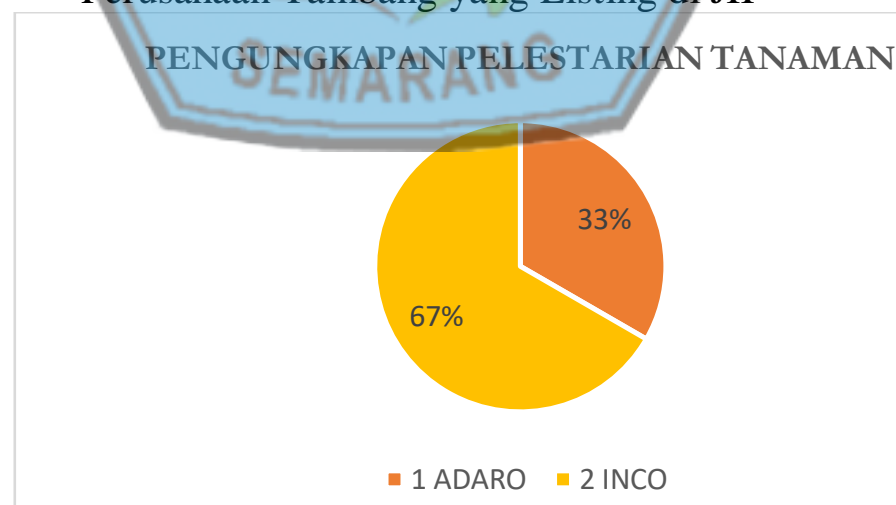

PT Adaro Energy melakukan penyemaian dan melakukan pembibitan di lokasi pembibitan untuk mendukung tanaman reklamasi di lapangan maupun penghijauan di lingkungan sekitar tambang dan melakukan kegiatan penanaman yang dilakukan dengan hydroseeding maupun penanaman manual serta melakukan pemeliharaan untuk merawat tanaman reklamasi yang meliputi pemupukan dan pembersihan gulma. Selain itu, perusahaan juga melakukan rehabilitasi Daerah Aliran Sungaim(DAS) di taman Hutan Raya Sultan Adam, sebagai bentuk pemenuhan terhadap 
kewajiban sebagai penerima ijin Pinjam Pakai Kawasan Hutan (IPPKH).

PT Vale Indonesia melakukan upaya penyediaan bibit-bibit tanaman local yang langka di fasilitas pembibitan untuk melestarikan tanaman. Selain itu, PT Vale Indonesia melakukan proses reklamasi pascatambang meliputi tahapan penutupan tambang, penimbunan lahan pascatambang dan pelapisan tanah pucuk. Kemudian dilakukan pengendalian erosi, pembangunan drainase, pembangunan jalan revegetasi, penanaman pohon perintis dan endemic, perawatan dan pemeliharaan tanaman, pemantauan keberhasilan dan pemanfaatan. Perusahaan juga memberi perhatian khusus pada keanekaragaman hayati yang ada disekitar wilayah operasi, khususnya di Sorowako.

\section{Pengungkapan terkait dengan Sumberdaya lainnya (Other Related Resources)}

Gambar 5. Pengungkapan Pelestarian Sumber Daya Lain

Perusahaan Tambang yang Listing di JII

SUMBER DAYA LAIN

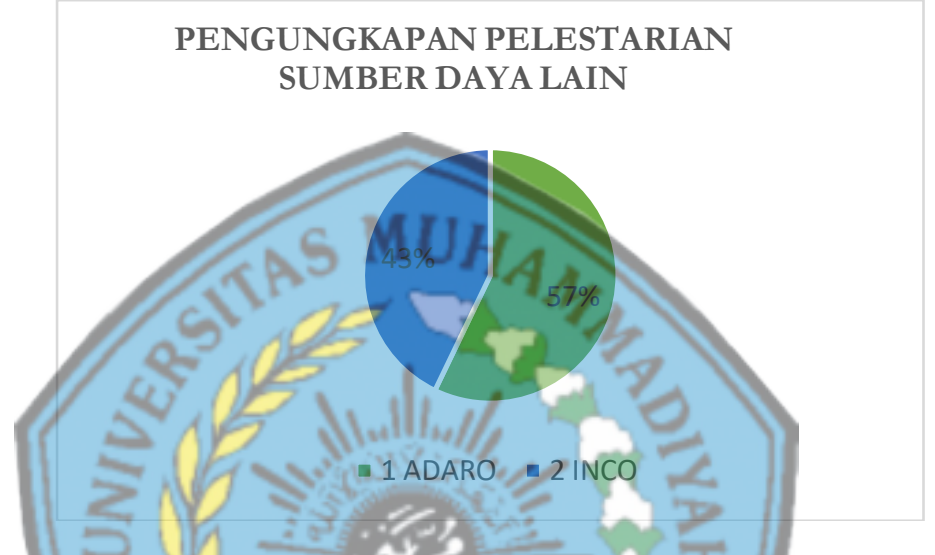

Pengungkapan yang dilakukan oleh PT Adaro Energy terkait dengan pelestarian sumber daya lain adalah dengan melakukan

upaya pengelolaan lahan reklamasi yang berkelanjutan dalam wujud perlindungan keanekaragaman hayati. Dalam program yang dilakukan oleh Adaro energy, perusahaan mengubah area reklamasi di Paringin yang diperuntukkan untuk Kawasan perlindungan habitat dan satwa dengan total 13,06 ha. Kawasan tersebut ditanami berbagai tanaman seperti akasia, sengon, trembesi dan ekaliptus. Hal ini menyebabkan banyak spesies fauna yang menjadikan area reklamasi menjadi habitatnya.

Pengungkapan terkait dengan sumber daya lain diungkapkan oleh PT Vale Indonesia dalam bentuk pengurangan ketergantungan terhadap bahan bakar fosil untuk pabrik pengolahan. Sebanyak 94\% dari konsumsi energi PT Vale Indonesia berasal dari energi yang terbarukan. Dengan mengurangi penggunaan bahan bakar fosil berarti mengurangi emisi karbon, yaitu dengan cara pengoperasian pembangkit listrik tenaga air.

PT Vale Indonesia juga berupaya untuk melestarikan sumber daya yang terkait lainnya. Misalkan dalam upaya menanggulangi penurunan kualitas udara, langkah kebijakan yang dilakukan adalah menyiram jalan tambang secara berkala pada jalan-jalan yang tidak beraspal dan menanam pohon di areal tambang untuk mengurangi debu yang mengarah ke daerah pemukiman. 
Gambar 5. Pengungkapan Lingkungan secara Keseluruhan Perusahaan Tambang yang Listing di JII

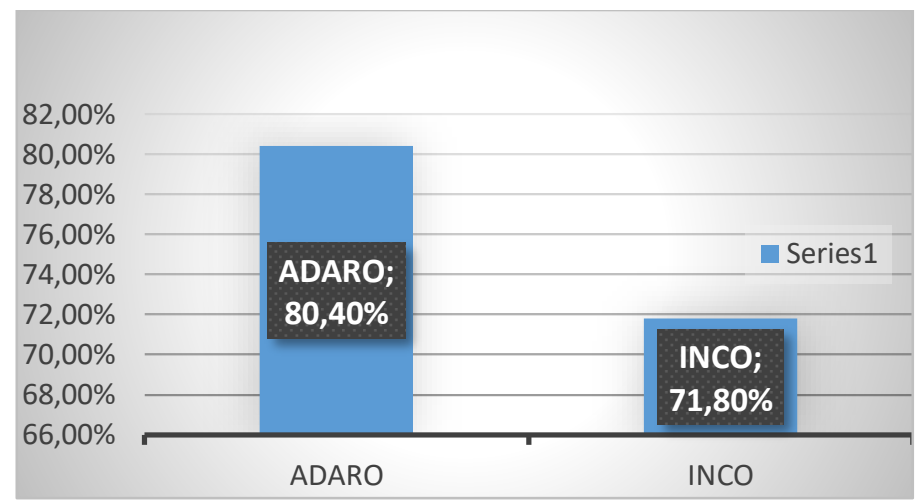

Dari data diatas dapat dilihat bahwa secara keseluruhan Adaro Energy

mengungkapkan pelestarian Qur'an. Hal ini ditunjukkan dengan lingkungan lebih banyak dibandingkan hampir semua komponen sudah dengan Vale Indonesia. Dimana besarnya pengungkapan Adaro energy sebesar $80.40 \%$ dan Vale Indonesia sebesar $71.80 \%$. Secara keseluruhan pengungkapan yang telah dilakukan oleh perusahaan tambang yang listing di JII diungkapkan lebih dari 50\%. Perusahaan Adaro Energy secara keseluruhan lebih banyak dalam mengungkapkan upaya dalam mengatasi masalah lingkungan. telah cukup baik, hal ini terlihat dari besarnya pengungkapan yang lebih dari $60 \%$. Upaya-upaya yang dilakukan oleh kedua perusahaan tersebut sudah cukup baik, hal ini dilihat dari berbagai inovasi dalam upaya mengurangi limbah dan polusi dengan cara menciptakan produk yang dapat meminimalkan krisis ekologi. Hasil ini juga mencerminkan komitmen perusahaan untuk menjaga kelestarian alam, bahwa perusahaan tidak hanya mengeruk hasil bumi saja untuk kepentingan perusahaan tetapi juga berusaha untuk menjaga kelestarian hidup.

\section{KESIMPULAN}

Dari data yang sudah disajikan, dapat disimpulkan bahwa sebagian besar perusahaan telah mengungkapkan pertanggungjawaban lingkungan berdasarkan item-item yang ada di AlAbdelzaher, D. M., \& Abdelzaher, A. (2015). Beyond Environmental Regulations: Exploring the Potential of "Eco-Islam" in Boosting Environmental Ethics Within SMEs in Arab Markets. Journal of Business Ethics, 145(2), 357-371.
Secara keseluruhan Adaro Energy megungkapkan sebesar $80.40 \%$ dan Vale Indonesia sebesar $71.80 \%$. Hal ini menunjukkan bahwa perusahaan tambang memiliki tingkat kepatuhan yang tinggi terkait dengan pengungkapan lingkungan seperti yang telah diatur dalam ayat-ayat Al-Qur'an. Perusahaan senantiasa melakukan inovasi baik pada produk maupun pada penggunaan alat produksi, dimana mereka memilih alat produksi yang dapat meminimalkan kerusakan lingkungan. Kesadaran perusahaan akan pelestarian lingkungan mendapatkan dukungan dari masyarakat dan dari pemerintah sebagai regulator. Diharapkan dengan adanya kesadaran dari semua pihak akan dapat menjaga alam ini agar dapat dipergunakan oleh generasi yang akan datang.

\section{DAFTAR PUSTAKA}

https://doi.org/10.1007/s10551-0152833-8

Banerjee, S. B. (2002). Corporate environmentalism The construct and its measurement, 55, 177-191.

Beekun, R. I., \& Badawi, J. A. (2005). Balancing ethical responsibility 
among multiple organizational stakeholders: The Islamic perspective. Journal of Business Ethics, 60(2), 131-145. https://doi.org/10.1007/s10551-0048204-5

Ekwueme, C. M., Egbunike, C. F., \& Onyali, C. I. (2013). Benefits of Triple Bottom Line Disclosures on Corporate Performance: An Exploratory Study of Corporate Stakeholders, 3(2), 79-91. https://doi.org/10.5539/jms.v3n2p79

Helfaya, A., \& Moussa, T. (2017). Do Board's Corporate Social Responsibility Strategy and Orientation Influence Environmental Sustainability Disclosure? Evidence. Business Strategy and the Environment, 26(8), 1061-1077. https://doi.org/10.1002/bse.1960

Hope, A. L. B., \& Jones, C. R. (2014). The impact of religious faith on attitudes to environmental issues and Carbon Capture and Storage (CCS) technologies: A mixed methods study. Technology in Society, 38, 48 59.

https://doi.org/10.1016/j.techsoc.201 4.02.003

Kamla, R., Gallhofer, S., \& Haslam, J (2006). Islam, nature and accounting: Islamic principles and the notion of accounting for the environment. Accounting Forum, 30(3), 245-265.

The Holy Quran

https://doi.org/10.1016/j.accfor.2006 .05 .003

Rizk, R. (2014). Islamic environmental ethics. Journal of Islamic Accounting and Business Research, 5(2), 194204.

Ratri Ratnasari,"Corporate Social Responsibility,Tanggungjawab Sosial atau Strategi Perusahaan ?" Thesis. 2013

Rusdiana,"Membumikan Etika Lingkungan bagi Upaya Membudayakan Pengelolaan Lingkungan yang Bertanggung Jawab",Vol.IX, No 2 (Juli 2015), 244-263.

Yook, K. H., Song, H., Patten, D. M., \& Kim, I. W. (2017). The disclosure of environmental conservation costs and its relation to eco-efficiency: Evidence from Japan. Sustainability Accounting, Management and Policy Journal, 8(1), 20-42. https://doi.org/10.1108/SAMPJ-072016-0039

https://www.cnnindonesia.com/ekonomi/ 20181017201447-85-

339319/inalum-sebut-isulingkungan-hambat-prosesdivestasi-freeport

https://www.voaindonesia.com/a/miningfor-life-berupaya-perbaiki-citraburuk-industritambang/4756704.html

\author{
.
}




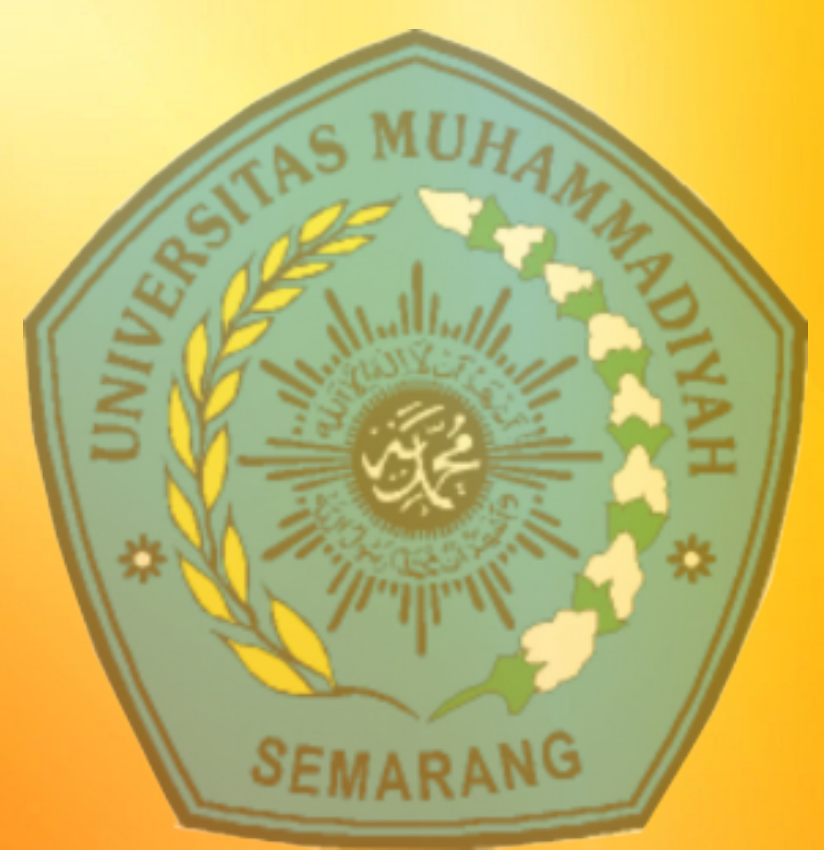

Penerbit :

Program Studi S1 Akutansi

Fakultas Ekonomi UNIMUS

KeduPFNGUNGKAPANHINGKUNGAN..18 Semarang 50273

Emaiborfe_unimus@yahoo.co.id

Telp. (024) 8502720 / Fax : (024) 8445 http:/jurnal.unimus.ac.id

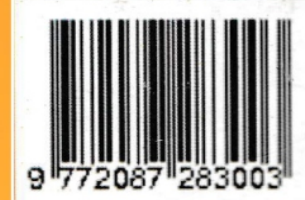

